\title{
HBsAg and Anti-HCV Prevalence among Pregnant Women Accessing Antenatal Care in a Tertiary Healthcare Facility in Central Nigeria
}

\section{Oti BV ${ }^{*}$, Pennap GR and Ngari HR}

Department of Microbiology, Nasarawa State University, Keffi, Nigeria

*Corresponding author: Oti BV, Department of Microbiology, Nasarawa State University, P. M. B. 1022, Keffi, Nigeria, Tel: +2347069657739; E-mail: Obabavictor1@gmail.com

Received Date: December 12, 2017; Accepted Date: January 03, 2018; Published Date: January 10, 2018

Copyright: @ 2018 Oti BV, et al. This is an open-access article distributed under the terms of the Creative Commons Attribution License, which permits unrestricted use, distribution, and reproduction in any medium, provided the original author and source are credited.

\begin{abstract}
Background: Hepatitis B and C viral infections during pregnancy are associated with high risk of maternal complications and mortality. There is high prevalence of vertical transmission causing fetal and neonatal hepatitis which can have serious effects on the neonate, leading to impaired physical and mental health later in life. This study was aimed at evaluating HBsAg and Anti-HCV prevalence of these viruses among pregnant women accessing antenatal care in Federal Medical Centre, Keffi, Nigeria.
\end{abstract}

Materials and methods: This prospective cross sectional study took place between May-July 2016. A total of 200 blood samples were collected from pregnant women after informed consent and self-administered questionnaires were completed. Blood samples were analyzed using HBsAg and anti-HCV immunochromatographic screening kits (Fastep Polymed Therapeutics Inc, USA). Chi square test (Smith's Statistical Package Version 2.80, California, USA) was used for assessing the association of risk factors with the infections.

Results: The overall level of positivity for both viruses in the study population was $14.0 \%$. The prevalence of HBsAg was $8.0 \%$ while Anti-HCV was $6.0 \%$ and no woman was coinfected with the 2 viruses. The infection rate was highest among those aged 21-30 years old and 31-40 years old for HBV and HCV respectively $(p>0.05)$. There was a statistically significant association between the viral infections and history of blood transfusion $(p<0.05)$. Surgical/ dental procedure was also a predictor for HCV infection $(p<0.05)$ and was not a predictor for HBV infection $(p>0.05)$ in this study. However, educational status, stage of pregnancy, type of marriage, parity and scarification marks did not show any statistically significant association with HBV and HCV infections $(p>0.05)$, although there were arithmetic differences among the studied risk factors $(p>0.05)$.

Conclusion: The study confirms a high prevalence of HBsAg and Anti-HCV among pregnant women in Central Nigeria which is a serious public health problem that cannot be downplayed. Therefore, there is need for establishment of public health measures in order to reduce disease burden and vertical transmission, including routine screening of all pregnant women for these viruses.

Keywords: Prevalence; HBV; HCV; Pregnant women

\section{Introduction}

Hepatitis B virus (HBV) is a double-stranded circular DNA virus of complex structure, classified as an Orthohepadnavirus in the family Hepadnaviridae while Hepatitis $\mathrm{C}$ virus $(\mathrm{HCV})$ is a single stranded linear ssRNA virus in the family Flaviviridae [1]. About 350 million and 190 million persons globally are infected with HBV and HCV respectively and are at high risk of death from active hepatitis, liver cirrhosis and hepatocellular carcinoma $[2,3]$. The prevalence of HBV infection is categorized as high ( $\geq 8 \%)$, intermediate $(2-7 \%)$, and low $(<2 \%)$ [4]. In developed and developing regions, the infection rates of hepatitis is around $0.1 \%$ and $3-20 \%$ respectively [4]. Fifty percent of new infections are implicated to vertical transmission during pregnancy, a record that is linked to the fact that routine HBV screening is not incorporated during antenatal care in the area [5].

Almost 40,000 children are born every year to HCV-infected women, resulting in up to 4000 new perinatally infected children yearly [6]. Several studies have shown an improvement in the biochemical markers of liver damage in $\mathrm{HCV}$ infected women during pregnancy $[7,8]$. This phenomenon was seen during hemodilution in pregnancy because the transaminase levels returned to pre-pregnancy levels shortly after delivery. However, changes in the immune response during pregnancy can possibly play a significant role in HCV interaction [8]. Contrary to the improved indices of liver dysfunction, a linear increase in HCV viremia has been reported throughout pregnancy [9], a fact that may be compatible with impaired immune reactivity. Several studies around the world have recommended that pregnant women should be screened for hepatitis B and C before delivery, as this reduces another generation from being infected by the viruses $[7,10,11]$.

The sexual transmission of hepatitis $\mathrm{B}$ and $\mathrm{C}$ has also been described, and the transmission of the hepatitis $\mathrm{B}$ virus has been found to be the more prevalent in this regard [12]. Many countries have already adopted proper blood screening procedures that have minimized the risk of such viruses being transmitted through blood transfusion $[13,14]$. HBV and HCV positive mothers with an HBsAg and anti-HCV positive status can vertically transmit the infections to their infants $[1,15]$. This risk of transmission may increase if the 
Page 2 of 4

mother develops the infections during the third trimester of pregnancy [16]. The health status of mothers and children in relation to hepatitis $\mathrm{C}$ infection has become a global concern [7]. The availability of effective screening methods for HCV has decreased the incidence of new cases of transfusion-associated hepatitis $\mathrm{C}$ infection in children [7]. However, childhood acquisition of $\mathrm{HCV}$ infection through vertical transmission has become one of the common routes of transmission [12]. HCV is also commonly transmitted through the injection of drugs, inadequate sterilization of medical equipment, especially syringes and needles and unscreened blood transfusion [12]. Testing for $\mathrm{HBV}$ and $\mathrm{HCV}$ infections in pregnancy should not be overemphasized in view of the morbidity and mortality of the pregnant women, its effect on the process of parturition, and the risk of vertical transmission [7]. Vaccination against $\mathrm{HBV}$ to stop vertical transmission can only be applied when the status of the pregnant woman is known [9].

Most HBV and HCV infections have been found to occur within the first 5 years of life in high endemicity regions of Africa through perinatal and horizontal transmission and approximately $25 \%$ of infected infants will die of HBV and HCV related chronic liver disease in adulthood [11,14]. Consequently, unless HBV and HCV infected pregnant women and associated factors for the infections are identified and adequate treatment provided, their babies are at high risk of the infections and its complications later in life [15]. Unfortunately, few studies have addressed infections with HBV and HCV among pregnant women in Central Nigeria. This study was conducted to evaluate the HBsAg and anti-HCV prevalence among pregnant women accessing antenatal care in a tertiary healthcare facility in Central Nigeria.

\section{Materials and Methods}

\section{Study area and population}

The study area for this research was Keffi. It is approximately $68 \mathrm{Km}$ from Abuja, the Federal Capital Territory and $128 \mathrm{Km}$ from Lafia, the capital of Nasarawa State. Keffi is located between latitude $85^{\prime} \mathrm{N}$ of the equator and longitude $78^{\prime} \mathrm{E}$ and situated on an altitude of $850 \mathrm{M}$ above sea level [17].

A total of 200 pregnant women accessing antenatal care at Federal Medical Centre Keffi participated in this prospective cross sectional study after an informed consent were obtained from each participant. Their demographic information was obtained by oral interview before sample collection.

\section{Sample collection}

About $5 \mathrm{ml}$ of blood was collected from each participant by venipuncture into a labeled plain tube. This was allowed to clot at room temperature and spun for 5 minutes at $3000 \mathrm{rpm}$. The sera were harvested into well labeled cryovials and stored at $-200^{\circ} \mathrm{C}$ until ready for use.

\section{HBsAg detection}

A one step rapid in vitro qualitative sandwich immunochromatographic diagnostic test kit (Fastep Polymed Therapeutics Inc, USA) was used for the detection of HBsAg in patient's serum. The test procedure and result interpretation were carried out according to the manufacturer's instructions.

\section{Anti-HCV detection}

A one step rapid in vitro qualitative sandwich immunochromatographic diagnostic test kit (Fastep Polymed Therapeutics Inc, USA) was used for the detection of anti-HCV in patient's serum. The test procedure and result interpretation were carried out according to the manufacturer's instructions.

\section{Ethical clearance}

Ethical clearance and approval to conduct this study was obtained from the Health Research Ethical Committee of Federal medical Centre, Keffi, Nigeria.

\section{Statistical analysis}

The prevalence of viral infections was determined and expressed as a percentage. This was further subjected to Chi-square statistical test (Smith's Statistical Package version 2.80, California, USA) to determine the statistical relationship between prevalence of the infections and the studied risk factors. A value of $\mathrm{p} \leq 0.05$ was accepted as statistically significant.

\section{Results}

Two hundred consented pregnant women were recruited for this study. Among them were $58(29.0 \%)$ aged less than 20 years old, 83 (41.5\%) aged 21-30 years old, 40 (20.0\%) aged 31-40 years old and 19 $(9.5 \%)$ aged greater than 41 years old. The overall prevalence of hepatitis in these pregnant women population was $14.0 \%$. Of these, $8.0 \%$ were reactive for $\mathrm{HBsAg}$ and $6.0 \%$ to anti-HCV antibodies and no woman was coinfected with the 2 viruses. The infection rate was highest among those aged 21-30 years old and 31-40 years old for HBV and HCV respectively $(\mathrm{p}>0.05)$. All the risk factors studied were not associated with the infections except for surgical /dental procedure which was statistically significant with $\mathrm{HCV}$ infection and History of blood transfusion was also associated with the both viruses $(\mathrm{p}<0.05)$ (Table 1).

\begin{tabular}{|c|c|c|c|c|c|}
\hline \multirow[t]{2}{*}{ Risk factors } & \multirow{2}{*}{$\begin{array}{l}\text { No. } \\
\text { Examined }\end{array}$} & \multicolumn{4}{|c|}{ No. Positive } \\
\hline & & HBV (\%) & p value & HCV (\%) & $p$ value \\
\hline Age (Years) & 58 & $5(8.6)$ & 0.8309 & $3(5.2)$ & 0.6736 \\
\hline$<20$ & 83 & $8(9.6)$ & & $6(7.2)$ & \\
\hline $21-30$ & 40 & $2(5.0)$ & & $3(7.5)$ & \\
\hline $31-40$ & 19 & $1(5.3)$ & & $0(0.0)$ & \\
\hline \multicolumn{6}{|l|}{$>41$} \\
\hline Educational status & 38 & $6(15.8)$ & 0.2738 & $5(13.2)$ & 0.2200 \\
\hline Non formal & 42 & $4(9.5)$ & & $3(7.1)$ & \\
\hline Primary & 79 & $4(5.1)$ & & $3(3.8)$ & \\
\hline Secondary & 41 & $2(4.9)$ & & $1(2.4)$ & \\
\hline \multicolumn{6}{|l|}{ Tertiary } \\
\hline Stage of Pregnancy & 70 & $4(5.7)$ & 0.1602 & $6(8.6)$ & 0.5738 \\
\hline 1st trimester & 45 & $7(15.6)$ & & $2(4.4)$ & \\
\hline 2nd trimester & 85 & $5(5.9)$ & & $4(4.7)$ & \\
\hline 3rd trimester & & & & & \\
\hline Type of Marriage & 88 & $8(9.1)$ & 0.6421 & $7(8.0)$ & 0.3321 \\
\hline
\end{tabular}




\begin{tabular}{|c|c|c|c|c|c|}
\hline $\begin{array}{l}\text { Monogamous } \\
\text { Polygamous }\end{array}$ & 112 & $8(7.1)$ & & $5(4.5)$ & \\
\hline $\begin{array}{l}\text { Parity } \\
\text { Primagravida } \\
\text { Multigravida }\end{array}$ & $\begin{array}{l}102 \\
98\end{array}$ & $\begin{array}{l}10(9.8) \\
6(6.1)\end{array}$ & 0.3756 & $\begin{array}{l}7(6.9) \\
5(5.1)\end{array}$ & 0.6215 \\
\hline $\begin{array}{l}\text { Surgical/Dental } \\
\text { procedures } \\
\text { Yes } \\
\text { No }\end{array}$ & $\begin{array}{l}72 \\
128\end{array}$ & $\begin{array}{l}7(9.7) \\
9(7.0)\end{array}$ & 0.5356 & $\begin{array}{l}8(11.1) \\
4(3.1)\end{array}$ & 0.0332 \\
\hline $\begin{array}{l}\text { History of Blood } \\
\text { Transfusion } \\
\text { Yes } \\
\text { No }\end{array}$ & $\begin{array}{l}46 \\
154\end{array}$ & $\begin{array}{l}9(19.6) \\
7(4.5)\end{array}$ & 0.0032 & $\begin{array}{l}6(13.0) \\
6(3.9)\end{array}$ & 0.0346 \\
\hline $\begin{array}{l}\text { Scarification Marks } \\
\text { Tribal marks } \\
\text { Tattoos/Traditional } \\
\text { dyes } \\
\text { None }\end{array}$ & $\begin{array}{l}41 \\
18 \\
141\end{array}$ & $\begin{array}{l}5(12.2) \\
3(16.7) \\
8(5.7)\end{array}$ & 0.2064 & $\begin{array}{l}5(12.2) \\
2(11.1) \\
5(3.5)\end{array}$ & 0.1102 \\
\hline
\end{tabular}

Table 1: HBsAg and anti-HCV prevalence among pregnant women accessing antenatal care in Federal Medical Centre, Keffi with respect to risk factors studied.

\section{Discussion}

With so much emphasis given to the study of HIV infection among pregnant women in Nigeria in recent years, little attention has been drawn to Hepatitis B and C viral infections which have been shown to have similar modes of transmission as the Human Immunodeficiency Virus. Information on HBV and HCV infections among pregnant women in Nigeria are sparse. This study therefore focused on evaluating HBsAg and anti-HCV prevalence among pregnant women accessing healthcare in Federal Medical Centre, Keffi, Nigeria.The prevalence of hepatitis carriage among participant in this study was $14.0 \%$. This is higher than findings of $6.7 \%$ in Edo [9], 5.8\% in Yenagoa [11], 5.7\% in Lagos [14] and 2.58\% in Pakistan [5].

HBsAg the seromarker used for HBV detection in this study was found in $8.0 \%$ of the women. This is in agreement with WHO groupings which states any prevalence $(\geq 8 \%)$ is hyperendemic $[15,18]$. This prevalence is lower than finding of $12.5 \%$ in Benin City [12] but higher than findings of 3.9\% in Kaduna [10], 4.2\% in Lagos [14], 5.3\% in Yenagoa [11] and 5.6\% in Edo [9] among pregnant women. Reports from other countries found 2.4\% in Ghana [16], 6.0\% in Ethiopia [18], $11.0 \%$ in Sudan [3], 1.16\% in Pakistan [5], 8.03\% in Tanzania [19], $5.44 \%$ in Laos [4] and 5.50\% in India [20]. These might be attributed to socio-demographic differences, cultural and behavioural differences for the risk factors of HBV infections, methodological difference and natural difference linked with various geographical situations. Of note is also the fact that the prevalence reported in this study did not account for occult HBV infection.

Similarly, the anti-HCV detection in this study was $6.0 \%$. This is higher than reports of $1.10 \%$ in Edo [9], 3.6\% in Benin City [12] and $1.5 \%$ in Lagos [14]. Similar studies from other countries recorded $2.6 \%$ in Rwanda [8] and $1.42 \%$ in Pakistan [5]. The different geographical location, predominant route of transmission, predominance of risk factors and the socio-biological factors of study subjects might be the reasons for the observed variation.

The age stratification in this study did not show any significant association in age specific prevalence $(\mathrm{P}>0.05)$ although there was arithmetic difference. HBsAg was detected highest among pregnant women that were aged 21-30 years old while anti-HCV was more among those aged 31-40 years old. This is in consonance with similar studies in Nigeria and other countries $[8-10,14,16]$ but contradicts Desalgn et al. [18] report in Ethiopia.

With reference to educational status, pregnant women with nonformal education recorded the highest prevalence (15.8\%) for both $\mathrm{HBV}$ and $\mathrm{HCV}$ infections. There was no statistically significant association between the viral infections and educational status ( $p>$ 0.05) but some degree of arithmetic difference was observed. Education has long been acknowledged to be of great value in our lives. It helps in making useful decision and sourcing of information concerning health and healthy living. More improved level of hygiene is related to higher levels of education. Mutagoma et al. [8] in Rwanda and Desalgn et al. [18] in Ethiopia reported same in a similar study.

The infections were not associated with stage of pregnancy $(\mathrm{p}>0.05)$. It was highest $(15.6 \%)$ in 2 nd trimester pregnant women for $\mathrm{HBV}$ infection while $\mathrm{HCV}$ prevalence was highest among pregnant women on their 1st trimester (8.6\%). This might be due to vertical transmission which is thought to be a major route of transmission among pregnant women in endemic areas. Such was also reported in similar study in Tanzania [19,21] and in Ghana [16].

Types of marriage, parity and surgical/dental procedure are not possible predictors for Hepatitis $\mathrm{B}$ and $\mathrm{C}$ viruses among the study population $(p>0.05)$ although surgical/dental procedure was a predictor for $\mathrm{HCV}$ infection $(\mathrm{p}<0.05)$. It was higher for both viruses among those in monogamous marriage, those with primagravida and those that had had a surgical/dental procedure for both viruses. It is in agreement with similar studies in Nigeria $[9,10]$, in Sudan [3] and in Ghana [16].

History of blood transfusion was found to be associated with the viral prevalence, although both infections were higher among those that had had a blood transfusion than those without a history of blood transfusion $(\mathrm{p}<0.05)$. This might be because there is no improvement in screening of the viruses from blood donors before transfusion in Keffi. This report correlates the studies of Aba and Aminu, [10], Oladeinde et al. [9], Ezechi et al. [14] in Nigeria but disagrees with the report of Yohanes et al. [13] in Ethiopia.

There was no statistically significant association between scarification marks and the viral infections $(p>0.05)$. HBsAg was highly reactive among those with tattoos/traditional dyes (16.7\%) while anti-HCV react more among those with a tribal marks (12.2\%). Other researchers have made similar observations in Nigeria [10] and Sudan [3].

\section{Conclusion}

High HBsAg of (8.0\%) and anti-HCV (6.0\%) prevalence among pregnant women accessing antenatal care were reported in this study according to World Health Organization's classification. This study provides a base to educate policymakers and stakeholders on the need to accelerate progress in accessibility to treatment and universal preventive measures of mother-to-child transmission (PMTCT) services for the viral infections in Keffi and beyond. The need of health 
Citation: Oti BV, Pennap GR, Ngari HR (2018) HBsAg and Anti-HCV Prevalence among Pregnant Women Accessing Antenatal Care in a Tertiary Healthcare Facility in Central Nigeria. Hepatol Pancreat Sci 2: 110. doi:10.4172/ 2573-4563.1000110

Page 4 of 4

education should not be over emphasized, particularly with the observed predictors such as surgical/dental procedure and scarification marks as a direct inflict of existing health facilities.

\section{Acknowledgement}

Our profound gratitude goes to the Management of Federal Medical Centre, Keffi, Nigeria for permission to carry out this study and the pregnant women who agreed to participate in our study. We dedicate this work to the blessed memory of Oti Baba Patrick, PhD.

\section{Conflict of Interest}

No conflict of interest found.

\section{References}

1. Pennap RG, Oti BV, Alaribe AG, Ajegena SA, Galleh PR (2017) Seroprevalence of Hepatitis B and C viruses among human immunodeficiency virus infected patients accessing healthcare in Federal Medical Centre, Keffi, Nigeria. Journal of Advances in Microbiology 3: 1-6.

2. World Health Organization (2015) Global alert and response. WHO, Geneva.

3. Kirbak ALS, Nganga Z, Omolo J, Idris H, Usman A, et al. (2017) Seroprevalence for Hepatitis B virus among pregnant women attending antenatal clinic in Juba Teaching Hospital, Republic of South Sudan. Pan Afr Med J 26: 72.

4. Choisy M, Keomalaphet S, Xaydalasouk K, Quet F, Lattaphasavang V, et al. (2017) Prevalence of Hepatitis B virus infection among pregnant women attending antenatal clinics in Vientiane, Laos, 2008-2014. Hepatitis Research and Treatment 2017: 5.

5. Ahmad I (2016) Prevalence of Hepatitis B and C viral infection among pregnant women in Peshawar, Pakistan. Hepat Mon 16: e36383.

6. Khayriyyah MH, Groeger J, Flaxman AD, Wiersma ST (2013) Global epidemiology of Hepatitis $\mathrm{C}$ virus infection: New estimates of age-specific antibodies to HCV seroprevalence. Hepatology 57: 42-1333.

7. World Health Organization (2014) Guidelines for the screening, care and treatment of persons with Hepatitis C infection. WHO, Geneva.

8. Mutagoma M, Balisanga H, Sebuhoro D, Mbituyumuremyi A, Remera E, et al. (2017) Hepatitis C virus and Human immunodeficiency virus coinfection among pregnant women in Rwanda. BMC Infect Dis 17: 167.

9. Oladeinde BH, Omoregie R, Olley M, Anunibe JA, Oladeinde OB (2012) Hepatitis $\mathrm{B}$ and $\mathrm{C}$ viral infections among pregnant women in a rural community of Nigeria. International Journal of Basic and Applied Virology 1: 1-5.

10. Aba HO, Aminu M (2016) Seroprevalence of Hepatitis B virus serologic markers among pregnant Nigerian women. Ann Afr Med 15: 7-20.

11. Buseri FI, Seiyaboh E, Jeremiah ZA (2010) Surveying infections among pregnant women in the Niger Delta, Nigeria. J Glob Infect Dis 2: 203-211.

12. Ugbebor O, Aigbirior M, Osazuwa F, Enabudoso E, Zabayo O (2011) The prevalence of Hepatitis $\mathrm{B}$ and $\mathrm{C}$ viral infections among pregnant women. N Am J Med Sci 3: 238-241.

13. Yohanes T, Zerdo Z, Chufamo N (2016). Seroprevalence and predictors of Hepatitis $B$ virus infection among pregnant women attending routine antenatal care in Arba Minch Hospital, South Ethiopia. Hepatitis Research and Treatment 2016: 7.

14. Ezechi OC, Kalejaiye OO, Gab-Okafor CV, Oladele DA, Oke BO, et al. (2014) Seroprevalence and factors associated with hepatitis B and C coinfection in pregnant Nigerian women living with HIV infection. Pan Afr Med J 17: 197.

15. Bassey E, Moses A, Udo S, Umo A (2009) Parallel and overlapping Human immunodeficiency virus, Hepatitis $B$ and $C$ virus infections among pregnant women in the Federal Capital Territory, Abuja, Nigeria. Online Journal of Health Allied Science 8: 4.

16. Luuse A, Dassah S, Lokpo S, Ameke L, Noagbe M, et al. (2016) Seroprevalence of Hepatitis B surface antigen amongst pregnant women attending an antenatal clinic, Volta Region, Ghana. J Public Health Africa 7: 1-6.

17. Akwa VL, Binbol NL, Samaila KL, Marcus ND (2007) Geographical perspective of Nasarawa state. Onaivi Printing and Publishing company, Keffi.

18. Desalgn Z, Wassie L, Beyene HB, Mihret A, Ebstie YA (2016) Hepatitis B and Human immunodeficiency virus infection among pregnant women in resource-limited high endemic setting, Addis Ababa, Ethiopia: Implications for prevention and control measures. Eur J Med Res 21:16

19. Manyahi J, Msigwa Y, Mhimbira F, Majigo M (2017) High seroprevalence of hepatitis B virus and human immunodeficiency virus infections among pregnant women attending antenatal clinic at Temeke Municipal Health facilities, Dar es Salaam, Tanzania: A cross sectional study. BMC Pregnancy Childbirth 17: 109.

20. Khan S (2017) Magnitude of Hepatitis B infection in pregnant women and in clinically suspected infections hepatitis at a Tertiary care hospital in Ghaziabad, India. Asian Pac J Trop Dis 7: 14-17.

21. Zenebe Y, Mulu W, Yimer M, Abera B (2014) Seroprevalence and risk factors of Hepatitis B virus and Human immunodeficiency virus infection among pregnant women in Bahir Dar City, North West Ethiopia: A cross sectional study. BMC Infect Dis 14: 118. 